\title{
Genetic Relationships of Soft Rot Bacteria Isolated from Konjac in China by Amplified Fragment Length Polymorphism (AFLP) and 16S rDNA Gene Sequences
}

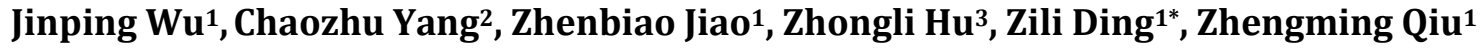 \\ ${ }^{1}$ Hubei Academy of Agricultural Sciences, Wuhan, China \\ ${ }^{2}$ Enshi Autonomous Prefecture Academy of Agricultural Sciences, Enshi, China \\ ${ }^{3}$ College of Life Sciences, Wuhan University, Wuhan, China \\ Email: 274184394@qq.com
}

Received 2 June 2015; accepted 21 July 2015; published 24 July 2015

Copyright @ 2015 by authors and Scientific Research Publishing Inc.

This work is licensed under the Creative Commons Attribution International License (CC BY).

http://creativecommons.org/licenses/by/4.0/

(c) (i) Open Access

\begin{abstract}
Twenty-three isolates of soft rot bacteria from konjac corms were examined for their diversity using 16S rDNAs and AFLP technology. Both methods clustered two groups, dependent on their biotype characterization of Pectobacterium carotovora subsp. carotovora (P.c.c) and Pectobacterium chrysanthemi (P.ch), respectively. Of all isolates, 17 (73.9\%) belonged to $P$. ch, indicated as the main pathogenic bacteria of konjac producing areas in China. The genetic variation among isolates from the same biotype was also rich, not consistent with the distances of the geographic sources.
\end{abstract}

Keywords

Soft Rot Bacteria, Identification, 16S rDNA, AFLP, Genetic Diversity

\section{Introduction}

Amorphophallus konjac (konjac) has long been planted in Southeast Asia and East Asia as food source and traditional medicine [1]. Previous study has reported that konjac soft rot caused by the genus Pectobacterium is one major reason of limited konjac products [2]. Based on yield data from the farmer, the yield of konjac suffering from soft rot bacteria decreased $30 \%$ to $50 \%$, and even more than $80 \%$ in some planting regions. Thus, soft rot is one of the most limiting factors in konjac production. At present, this kind of bacteria have been re-

*Corresponding author.

How to cite this paper: Wu, J.P., Yang, C.Z., Jiao, Z.B., Hu, Z.L., Ding, Z.L. and Qiu, Z.M. (2015) Genetic Relationships of Soft Rot Bacteria Isolated from Konjac in China by Amplified Fragment Length Polymorphism (AFLP) and 16S rDNA Gene Sequences. Agricultural Sciences, 6, 717-723. http://dx.doi.org/10.4236/as.2015.67069 
ported in other vegetables or ornamental crops, i.e. calla lilies [3] and potatoes [4] [5]. Waldee (1954) firstly reported this kind of pathogenetic bacteria, leading to soft rot, named as the genus Pactobacterium separated from the genus Erwina [6], and further divided it into two species, namely P. chrysanthemi and P. carotovorum [7].

With the development of molecular techniques, many methods, such as DNA-DNA hybridization [8] [9], ribotyping [10], ITS-PCR [11], 16S rDNA analyses [12] [13], and phenotypic techniques, including biochemistry [14] [15], have been used to research the genetic diversity of genus Pectobacterium, of which rDNA analysis is efficient as an important index of bacterial evolution and genetic relationship. Based on the differences of $16 \mathrm{~S}$ rDNA sequences, the taxonomic status and genetic diversity of bacteria can be determined. Besides, amplified fragment length polymorphism (AFLP) as a genomic fingerprinting method has been described by Vos et al. [16]. AFLP analysis has proven to be an effective research tool for discriminating DNA samples from a variety of bacterial species and strains [16]-[18].

The aims of this study were to investigate the genetic diversity and taxonomic classification of soft rot isolates from Konjac corm using AFLP technique and 16S rDNA sequences at species and subspecies levels, and to type strains for epidemiological investigations.

\section{Materials and Methods}

\subsection{Strains and Media}

24 bacteria isolates were isolated from soft rot corm of Amorphophallus konjac, obtained from the main konjac producing areas in China and Myanmar (Table 1). All isolates have been inoculated and confirm the suscepti-

Table 1. Bacteria isolates from the soft rot corm of konjac used in this study.

\begin{tabular}{|c|c|c|c|c|c|c|}
\hline \multirow{2}{*}{ Number } & \multirow{2}{*}{ Strain } & \multirow{2}{*}{ Geographical origin } & \multirow{2}{*}{$\begin{array}{l}\text { Species or } \\
\text { subspecies }\end{array}$} & \multirow{2}{*}{ Accession no. } & \multicolumn{2}{|c|}{ Cluster } \\
\hline & & & & & 16S rDNA & AFLP \\
\hline 1 & BaDongI & Enshi, Hubei, China & P.c.c & FJ906788 & $\mathrm{Ib}$ & $\mathrm{Ib}$ \\
\hline 2 & BaDongHuII & Enshi, Hubei, China & P.c.c & HM622350 & Ia & Ia \\
\hline 3 & SichuanI & Mianyang, Sichuan, China & P.c.c & FJ906790 & Ia & Ia \\
\hline 4 & SichuanII & Mianyang, Sichuan, China & P.c.c & FJ906791 & $\mathrm{Ib}$ & $\mathrm{Ib}$ \\
\hline 5 & MyanmarI & Myanmar & P.ch & HM590190 & IIa & IIa \\
\hline 6 & MyanmarIII & Myanmar & P.ch & HM590192 & IIa & IIa \\
\hline 7 & AnK2 & Ankang, Shanxi, China & P.ch & FJ463869 & IIc & $\mathrm{IIb}$ \\
\hline 8 & ShanXiI & Ankang, Shanxi, China & P.ch & FJ906792 & IIc & $\mathrm{IIb}$ \\
\hline 9 & ShanXiII & Ankang, Shanxi, China & P.ch & FJ906793 & IIa & IId \\
\hline 10 & NKYHuaYa & Wuhan, Hubei, China & P.c.c & HМ622348 & Ia & Ia \\
\hline 11 & NKYC & Wuhan, Hubei, China & P.c.c & FJ463871 & Ia & Ia \\
\hline 12 & $\mathrm{ZhXB}$ & Zhuxi, Hubei, China & P.ch & FJ463870 & IId & IIa \\
\hline 13 & HualI & Wuhan, Hubei, China & P.ch & FJ906794 & IId & IIa \\
\hline 14 & WuDaHuaYaI & Wuhan, Hubei, China & P.c.c & HM622345 & Ia & Ia \\
\hline 15 & CHQ & Chongqing, China & P.ch & FJ463865 & IId & IId \\
\hline 16 & AnKangIII & Ankang, Shanxi, China & P.ch & FJ906796 & IId & IId \\
\hline 17 & LiChuanII & Lichuan, Hubei, China & P.ch & FJ906795 & IId & IIa \\
\hline 18 & NKYA & Wuhan, Hubei, China & P.ch & FJ463863 & $\mathrm{IIb}$ & IIc \\
\hline 19 & WuFengII & Wufeng, hubei, China & P.ch & FJ906797 & IId & IIa \\
\hline 20 & YunNan & Yunnan, China & P.ch & HM590189 & $\mathrm{IIb}$ & IIc \\
\hline 21 & ESJSX & Enshi, Hubei, China & P.ch & FJ463864 & $\mathrm{IIb}$ & IIc \\
\hline 22 & ESH II & Enshi, Hubei, China & P.ch & FJ463867 & $\mathrm{IIb}$ & IIc \\
\hline 23 & ESHI & Enshi, Hubei, China & P.ch & FJ463866 & IIc & $\mathrm{IIb}$ \\
\hline 24 & ESH III & Enshi, Hubei, China & P.ch & FJ463868 & $\mathrm{IIb}$ & IIc \\
\hline
\end{tabular}

Note: P.c.c. and P.ch are the abbreviation of Pectobacterium carotovora subsp. carotovora and Pectobacterium chrysanthemi, respectively. 
bility (data not shown), and stored in the Luria-Bertani (LB) medium containing $30 \%$ (v/v) glycerol at $-80^{\circ} \mathrm{C}$. Before using in this study, bacteria were grown in LB broth at $28^{\circ} \mathrm{C}(200 \mathrm{r} / \mathrm{min})$ for $14-16$ hours.

\subsection{Extraction of Bacteria Genomic DNAs}

Genomic DNA was extracted from bacteria samples by using TIANamp Bacteria DNA Kit (TIANGEN, Co., China). These DNA templates were store at $-20^{\circ} \mathrm{C}$ for using. DNA concentrations were determined by measuring the $\mathrm{A}_{260}$ with a Uvikon model 940 spectrophotometer.

\subsection{Phylogenetic Analysis on the Basis of Partial 16S rDNA Gene Sequencing}

For 16S rDNA gene sequencing, the primers were used in this study: $\mathrm{P}_{1}$ (5'-AGACTTTGATCCTGGCTCAG-3') and $\mathrm{P}_{2}\left(5^{\prime}\right.$-CGGCTACCTTGTTACGACTTC-3') [19]. Each PCR reaction mixtures (25 $\mu$ l) contained $10 \mathrm{pM}$ of each primer, $0.5 \mathrm{mM}$ dNTPs (Dingguo Ltd., China), $0.4 \mathrm{mM} \mathrm{MgCl}_{2}, 1 \mathrm{U}$ of Taq polymerase and $\sim 10 \mathrm{ng}$ template-DNA. PCR amplifications were performed with the parameters: initial denaturation $\left(3 \mathrm{~min}\right.$ at $\left.95^{\circ} \mathrm{C}\right), 35$ cycles of amplification $\left(30 \mathrm{~s}\right.$ at $95^{\circ} \mathrm{C}, 30 \mathrm{~s}$ at $55^{\circ} \mathrm{C}, 90 \mathrm{~s}$ at $72^{\circ} \mathrm{C}$ ), and a final elongation of $8 \mathrm{~min}$ at $72^{\circ} \mathrm{C}$. All amplifications were performed in a Lifepro Thermal Cycler (Hangzhou Bioer Technology Co., Ltd). The PCR products were checked by electrophoresis on 1.0\% agarose gels (Sigma), and then the corresponding PCR products were purified with PureLink ${ }^{\mathrm{TM}}$ Quick kit (Invitrogen) following the recommended manufacturer. Purified products were further ligated into pGEM-T vectors (Promega Co., China), and then transformed into E. coli $D H-5 a$ cells. Positive colonies were selected for sanger sequencing by blue-white screening procedure [20]. Using these sequences, the phylogenetic tree was constructed by MEGA6.0 with the Neighbor-Joining method [21]. Bootstrap analysis with 1000 replicates was performed to calculate the support of branches. All $16 \mathrm{~S}$ rDNA sequences in this study have been doposited to the NCBI Genbank databases (Table 1).

\subsection{AFLP Analysis of Soft Rot Isolates}

Two endonucleases (EcoRI and MseI) were used for AFLP analysis in this study, and the reactions were performed as described previously with minor modification [16]. Firstly, bacterial genomic DNA $(\sim 0.2 \mu \mathrm{g})$ was digested with $10 \mathrm{U}$ each of restriction endonucleases in $1 \times$ EcoR I buffer (Thermo Scientific) for $3 \mathrm{~h}$ at $37^{\circ} \mathrm{C}$, and then $3 \mathrm{~h}$ at $65^{\circ} \mathrm{C}$. MseI and EcoRI adapters (Table 2) were ligated to the digested DNA in a total volume of 10 $\mu \mathrm{l}$ using T4 DNA ligase (Promega) for $12 \mathrm{~h}$ at $16^{\circ} \mathrm{C}$. After ligation, the ligated products were amplified by PCR using nonselective primers (EcoRI-00, MseI-00, Table 2) in a total volume of $20 \mu$ l. Each reaction mixture contained $2 \mu \mathrm{l}$ of the ligation mixture, $0.5 \mathrm{mM} \mathrm{Mg}^{2+}, 0.8 \mathrm{mM}$ dNTPs, $1 \mathrm{U}$ of Taq polymerase and $10 \mathrm{pmol}$ each of the EcoRI-00 and MseI-00 primers. The PCR was performed under the following conditions: 36 cycles of $30 \mathrm{~s}$ of denaturing at $94^{\circ} \mathrm{C}, 30 \mathrm{~s}$ of annealing at $56^{\circ} \mathrm{C}$, and $1 \mathrm{~min}$ of extension at $72^{\circ} \mathrm{C}$. All amplifications were performed in a Lifepro Thermal Cycler (Hangzhou Bioer Technology Co., Ltd). After PCR reaction, $10 \mu 1$ of gel loading buffer ( $94 \%$ formamide, $10 \mathrm{mM}$ EDTA, $0.5 \mathrm{mg}$ of xylene cyanol FF ml${ }^{-1}, 0.5 \mathrm{mg}$ of bromophenol blue $\mathrm{ml}^{-1}$ ) was added. Samples were heated to $95^{\circ} \mathrm{C}$ for $5 \mathrm{~min}$ and immediately cooled on ice. PCR products were electrophoresed using $6 \%$ polyacrylamide denaturing gel. Gels were stained with silver nitrate, following the protocol described by Han et al. [22].

Polymorphic AFLP bands were manually scored as binary data for the presence (1) or absence (0) of fragments ranged from 100 and 500bp. A table containing binary information was used to calculate Jaccard's pair

Table 2. List of oligonucleotide primers and adapters.

\begin{tabular}{cc}
\hline Adaptor name & Adaptor sequence (5'-3') \\
\hline EcoRI & 5'-CTC gTA gAC TgC gTA CC-3' 5'-AAT Tgg TAC gCA gTC-3' \\
MseI & 5'-gAC gAT gAg TCC TgA g-3' 5'-TAC TCA ggA CTC AT-3' \\
Primer name & Primer sequence (5'-3') \\
EcoRI-00 & gAC TgC gTA CCA ATT C A \\
MseI-00 & gAT gAg TCC TgA gTA A C
\end{tabular}


wise coefficients of similarity. All 24 bacteria isolates were clustered using the Unweighted Pair Group Method with Arithmetic averages (UPGMA) method and the SHAN clustering program by NTSYS [23].

\section{Results and Discussion}

In this study, a total of 24 bacteria isolates were used for diversity analysis using AFLP technology and 16S rDNA sequences. These bacteria were isolated from Myanmar ( 2 isolates) and 5 provinces in China (22 isolates), respectively (Figure 1). Before performing Molecular experiments, all isolates have been re-inoculated to normal konjac corm, and confirmed their susceptibility rDNA was an important index of bacterial evolution and genetic relationship. Based on the variation of $16 \mathrm{~S}$ rDNA sequences, the taxonomic status and genetic diversity of bacteria can be determined. Thus, we firstly compared $16 \mathrm{~S}$ rDNA sequences of 24 isolates with Nucleotide BLAST (http://blast.ncbi.nlm.nih.gov/Blast) in NCBI. The results shown soft rot bacteria of konjac conclude two biotypes: Pectobacterium carotovora subsp. vcarotovora (P.c.c) and Pectobacterium chrysanthemi (P.ch). Of which P.ch is mainly pathogenic bacteria (17/24, 71\%). Besides, The isolates located at the same region (i.e. Wuhan and Enshi) can exist two biotypes (P.c.c and P.ch), indicated the infection complexity of konjac soft rot. Based on 16S rDNA sequences, a phylogenetic tree was obtained, and showed a high of genetic diversity across 24 isolates (Figure 2). This results support the heterogeneous taxonomic structure of the genus Pectobacterium. The phylogenetic dendrogram included two groups (I and II), Group I (all P.c.c types) was further divided into two subgroups (Ia and Ib). Group II (all P.ch types) contained 4 subgroups (IIa, IIb, IIc and IId).

For further confirmed diversity of these isolates, AFLP analysis was done, and a total of 115 polymorphic DNA fragments ranging from 100 to $500 \mathrm{bp}$ were detected, and used to analyze the diversity of 24 bacteria stain isolates. Based on binary data, a Phylogenetic tree was constructed according to UPGMA method and the SHAN clustering program by NTSYS version $2.20 \mathrm{k}$. The results showed the genetic similarity varied from 0.51 to 0.98 . The dendrogram consisted of two major groups (Figure 3). Group I included all P.c.c isolates, and further clustered into two subgroups (Subgroup Ia, Ib) at the cutoff of the coefficient of 0.63. Subgroup Ib con-

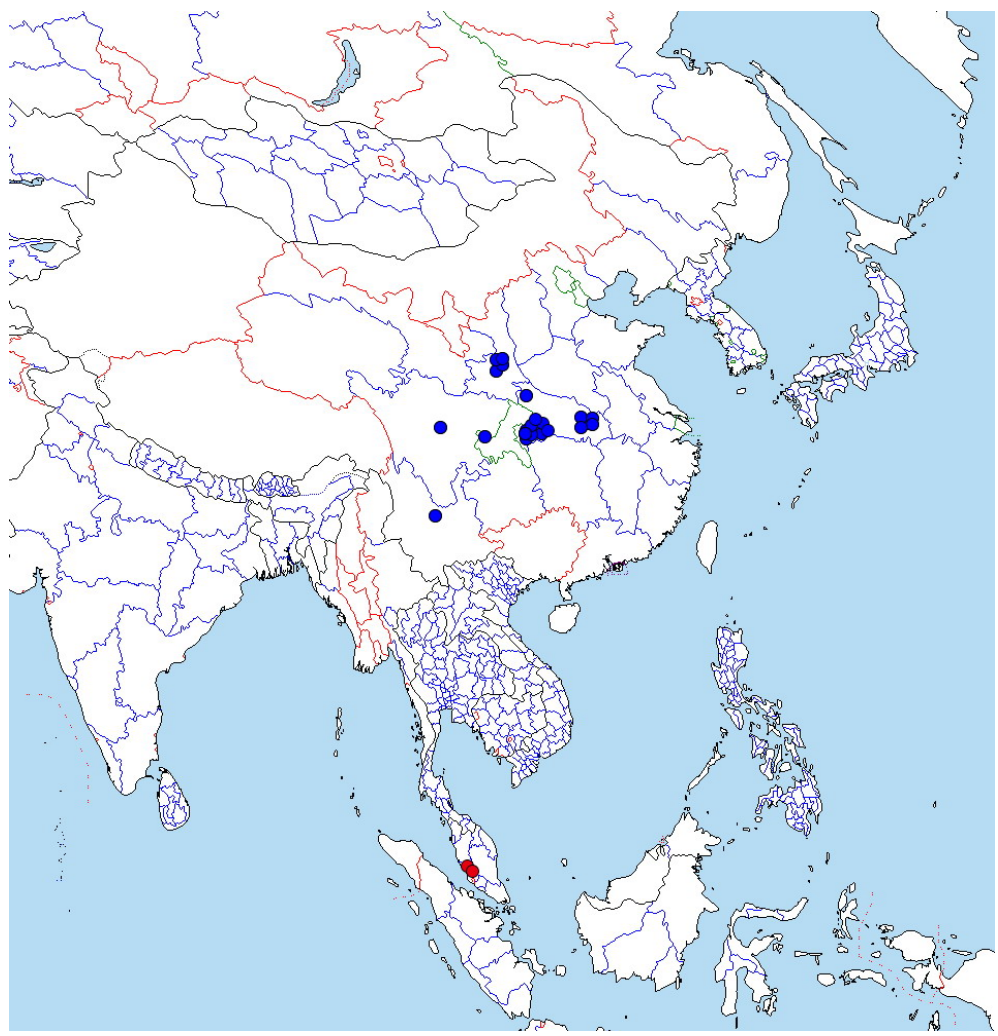

Figure 1. These bacteria were isolated from Myanmar (2 isolates) and 5 provinces in China (22 isolates). 


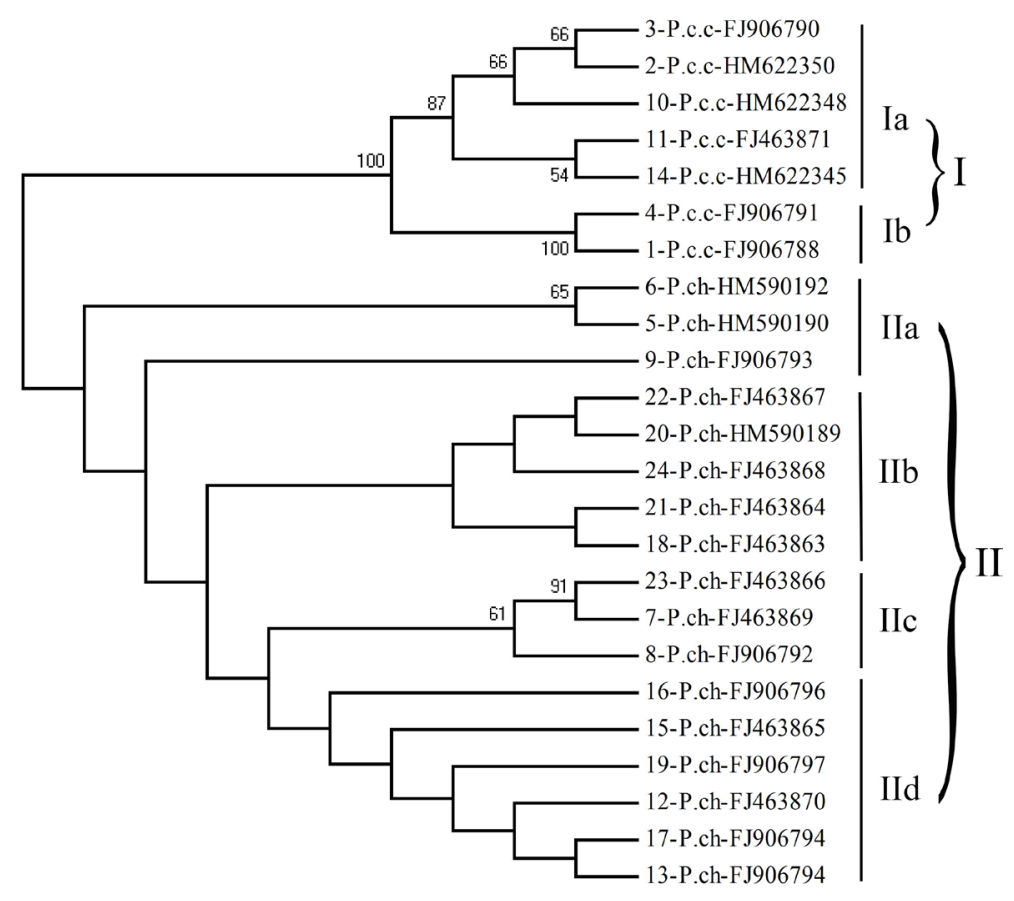

Figure 2. Phylogenetic dendrogram based on 16s rDNA gene sequences for soft rot isolates. The branching pattern was generated by the neighbor-joining method using MEG6.0. The numbers at the nodes indicate the levels of bootstrap support, and only the values more than 50 are given.

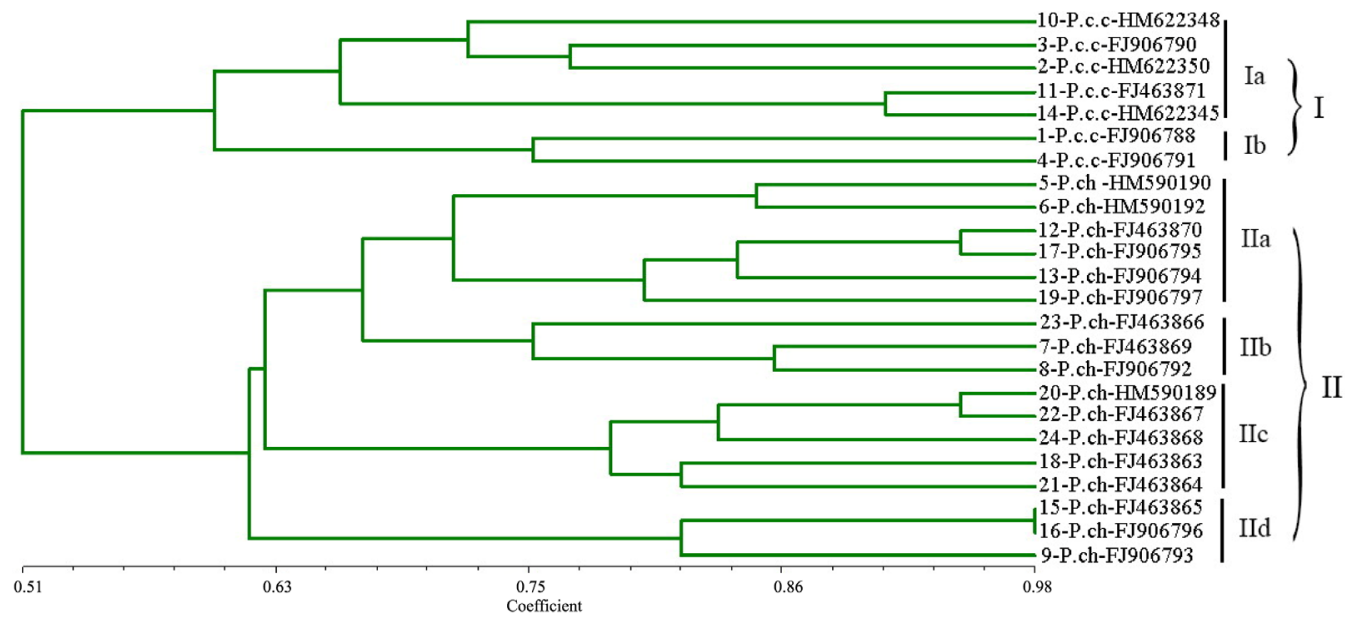

Figure 3. Dendrogram based on UPGMA clustering using AFLP data from the 24 soft rot isolates. The scale at the bottom indicates the degree of genetic relatedness between strains.

tained two isolates from Hubei and Sichuan province, China, respectively. Subgroup Ia comprised five isolates, of which 3-P.c.c-FJ906790 is the same geographic origin with 4-P.c.c-FJ906791 from subgroup Ib. All P.c.c isolates were clustered into Group II that further clustered into three subgroup (IIa, IIb, IIc and IId). Subgroup IIa included 6 isolates from Myanmar and Hubei, China, respectively. Subgroup IIb contained two Shanxi isolates and one Hubei isolates. Subgroup IIc possessed one Yunnan isolates and 4 Hubei isolates. Subgroup IId included 2 Shanxi and 1 Chongqing isolates. Obviously, based on the analysis of AFLP, the results support the heterogeneous taxonomic structure of genus Pectobacterium. And the genetic differences among isolates were not dependent on the resources of geographic area. The isolates from different province can be clustered into one group. 
At present, konjac cultivars resistant to the soft rot disease have not been reported. This disease is conventionally controlled by cultivation measures (such as crop rotation, intercropping) and chemical control [24]. Chemical control is usually inappropriate because pathogens can develop resistance and also pesticides can pollute the environment. Therefore, researchers pay much attention to the biological control. In this study, two kinds of pathological bacterial on konjac (P.c.c and P.ch) were found in China, based on genetic relationships of konjac soft rot bacteria by AFLP and $16 \mathrm{~S}$ rDNA sequences. This should contribute to understand pathological bacterial on konjac soft rot and research biological methods against Pectobacterium spp.

\section{Conclusion}

For konjac production, the soft rot is the most serious factor affecting its yield. To further understand constitution and diversity genetics of konjac soft rot bacteria, AFLP technique and 16S rDNA gene sequences were used to analyze the genetic diversity of 24 isolates collected from Malaysia and different regions in China. Through the 16S rDNA analysis, two kinds of pathogenic bacteria (P.c.c and P.ch) were identified, which was similar to previous reports. Meanwhile, there were two types of pathogens found in the same region, which indicated the complexity of the soft rot of konjac. In the phylogenetic tree, two clades were constructed depending on P.c.c and P.ch species, respectively; the genetic diversity within species was rich, and genetic differentiation among isolates was not based on the resource of geographic area.

\section{Acknowledgements}

This work was financially supported by National Science and Technology Supporting Program [Grant No. 2011BAD33B03], Hubei Public Science and technology Program [Grant No. 2013BBB08], Special Fund of Hubei Konjak Industry Development in 2013 and the Natural Science Foundation of China [31401706] and Wuhan Science \& Technology Planning Project (Grant No. 2014020101010075).

\section{References}

[1] Vasques, C.A., et al. (2008) Evaluation of the Pharmacotherapeutic Efficacy of Garcinia cambogia plus Amorphophallus konjac for the Treatment of Obesity. Phytotherapy Research, 22, 1135-1140. http://dx.doi.org/10.1002/ptr.2323

[2] Wu, J.P., et al. (2011) Molecular Detection of Pectobacterium Species Causing Soft Rot of Amorphophallus konjac. World Journal of Microbiology \& Biotechnology, 27, 613-618. http://dx.doi.org/10.1007/s11274-010-0496-2

[3] Gracia-Garza, J.A., et al. (2004) Increased Incidence of Erwinia Soft-Rot on Calla Lilies in the Presence of Phosphorous. European Journal of Plant Pathology, 110, 293-298. http://dx.doi.org/10.1023/B:EJPP.0000019799.17513.86

[4] Ali, H.F., et al. (2012) Inoculum Sources, Disease Incidence and Severity of Bacterial Blackleg and Soft Rot of Potato. Pakistan Journal of Botany, 44, 825-830.

[5] Ngadze, E., et al. (2012) Pectinolytic Bacteria Associated with Potato Soft Rot and Blackleg in South Africa and Zimbabwe. European Journal of Plant Pathology, 134, 533-549. http://dx.doi.org/10.1007/s10658-012-0036-z

[6] Waldee, E.L. (1945) Comparative Studies of Some Peritrichous Phytopathogenic Bacteria. Iowa State College Journal of Science, 19, 435-484.

[7] Toth, I., Avrova, A. and Hyman, L. (2001) Rapid Identification and Differentiation of the Soft Rot Erwinias by 16S-23S Intergenic Transcribed Spacer-PCR and Restriction Fragment Length Polymorphism Analyses. Applied and Environmental Microbiology, 67, 4070-4076. http://dx.doi.org/10.1128/AEM.67.9.4070-4076.2001

[8] Brenner, D.J., Fanning, G.R. and Steigerwalt, A.G. (1977) Deoxyribonucleic Acid Relatedness among Erwiniae and Other Enterobacteria II. Corn Stalk Rot Bacterium and Pectobacterium chrysanthemi. International Journal of Systematic and Evolutionary Microbiology, 27, 211-221. http://dx.doi.org/10.1099/00207713-27-3-211

[9] Gallois, A., et al. (1992) Erwinia carotovora subsp. odorifera subsp. nov., Associated with Odorous Soft Rot of Chicory (Cichorium intybus L.). International Journal of Systematic and Evolutionary Microbiology, 42, 582-588. http://dx.doi.org/10.1099/00207713-42-4-582

[10] Nassar, A., et al. (1994) Ribotyping of Erwinia chrysanthemi Strains in Relation to Their Pathogenic and Geographic Distribution. Applied and Environmental Microbiology, 60, 3781-3789.

[11] Xiu, J.H., Ji, G.H., Wang, M., Yang, Y.L. and Li, C.Y. (2006) Molecular Identification and Genetic Diversity in Konnyaku's Soft Rot Bacteria. Acta Microbiologica Sinica, 46, 522-525.

[12] Hauben, L., Moore, E.R., Vauterin, L., Steenackers, M., Mergaert, J., Verdonck, L. and Swings, J. (1998) Phylogenetic 
Position of Phytopathogens within the Enterobacteriaceae. Systematic and Applied Microbiology, 21, 384-397. http://dx.doi.org/10.1016/S0723-2020(98)80048-9

[13] Kwon, S.W., Go, S.J., Kang, H.W., Ryu, J.C. and Jo, J.K. (1997) Phylogenetic Analysis of Erwinia Species Based on 16S rRNA Gene Sequences. International Journal of Systematic Bacteriology, 47, 1061-1067. http://dx.doi.org/10.1099/00207713-47-4-1061

[14] Dickey, R.S. (1979) Erwinia chrysanthemi: A Comparative Study of Phenotypic Properties of Strains from Several Hosts and Other Erwinia Species. Phytopathology, 69, 324-329. http://dx.doi.org/10.1094/Phyto-69-324

[15] Dye, D.W. (1981) A Numerical Taxonomic Study of the Genus Erwinia. New Zealand Journal of Agricultural Research, 24, 223-229. http://dx.doi.org/10.1080/00288233.1981.10420894

[16] Vos, P., Hogers, R., Bleeker, M., Reijans, M., van de Lee, T., Hornes, M., et al. (1995) AFLP: A New Technique for DNA Fingerprinting. Nucleic Acids Research, 23, 4407-4414. http://dx.doi.org/10.1093/nar/23.21.4407

[17] Geornaras, I., Kunene, N.F., von Holy, A. and Hastings, J.W. (1999) Amplified Fragment Length Polymorphism Fingerprinting of Pseudomonas Strains from a Poultry Processing Plant. Applied and Environmental Microbiology, 65, 3828-3833.

[18] Janssen, P., Coopman, R., Huys, G., Swings, J., Bleeker, M., Vos, P., et al. (1996) Evaluation of the DNA Fingerprinting Method AFLP as an New Tool in Bacterial Taxonomy. Microbiology, 142, 1881-1893. http://dx.doi.org/10.1099/13500872-142-7-1881

[19] Weisburg, W.G., Barns, S.M., Pelletier, D.A. and Lane, D.J. (1991) 16S Ribosomal DNA Amplification for Phylogenetic Study. Journal of Bacteriology, 173, 697-703.

[20] Sambrook, J., Fritsch, E.F. and Maniatis, T. (1989) Molecular Cloning: A Laboratory Manual. Second Edition, Cold Spring Harbor Laboratory Press, Cold Spring Harbor.

[21] Tamura, K., Stecher, G., Peterson, D., Filipski, A. and Kumar, S. (2013) MEGA6: Molecular Evolutionary Genetics Analysis Version 6.0. Molecular Biology and Evolution, 30, 2725-2729. http://dx.doi.org/10.1093/molbev/mst197

[22] Han, Y.C., Teng, C.Z., Hu, Z.L. and Song, Y.C. (2008) An Optimal Method of DNA Silver Staining in Polyacrylamide Gels. Electrophoresis, 29, 1355-1358. http://dx.doi.org/10.1002/elps.200700558

[23] Rohlf, F. (2000) NTSYS-pc Version 2.10 m, Numerical Taxonomy and Multivariate Analysis System (Computer Program). Exeter Software, Steauket.

[24] Snijder, R.C., Cho, H.-R., Hendriks, M.M.W.B., Lindhout, P. and van Tuyl, J.M. (2004) Genetic Variation in Zantedeschia spp. (Araceae) for Resistance to Soft Rot Caused by Erwinia carotovora subsp. carotovora. Euphytica, 135, 119-128. http://dx.doi.org/10.1023/B:EUPH.0000009546.88984.60 